\title{
Sociological Research on Self-Employed Respondents in the Context of Developing Self- Employed Citizens' Education Management in the Conditions of Digitalization
}

\author{
Pavel Viktorovich Razov ${ }^{1 *}$, Yuriy Alekseevich Korablin ${ }^{1}$, Aleksey Yurievich Oborskiy ${ }^{1}$, \\ Alexey $V$. Novikov ${ }^{1}$, and Petr S. Shcherbachenko ${ }^{2}$ \\ ${ }^{1}$ Financial University under the Government of the Russian Federation, Department of Sociology, \\ History and Philosophy, Moscow, Russia \\ ${ }^{2}$ Financial University under the Government of the Russian Federation, Corporate Finance and \\ Corporate Governance Department, Moscow, Russia
}

\begin{abstract}
The authors' goal has been to show the need to improve both the general level of education of self-employed citizens, and, mainly, the actual level of specialized competencies. The modern world does not tolerate an unskilled approach in any business. Therefore, special education for selfemployed citizens is their internal need that has direct impact on their wellbeing and relevance in the modern labor market. Real digital technologies aim at improving comfort for self-employed citizens while realizing their need in specialized education. For efficient forecasting, the inductive analysis method has been chosen. This is when the current and previous situations in the self-employed market are examined, then the main factors of the market development are revealed, and the main reasons for the formalization of self-employment are considered. Based on this, the prospects for increasing the self-employed citizens' groups as consumers of general and specialized education are defined. Sociological instruments of this study include expert surveys, in-depth interviews, analysis of Internet publications of central print media, and content analysis.

The main results of the study are as follows:

- There is an exponential increase in the number of registered self-employed citizens - consumers of specialized education in the medium term.

- Self-employed citizens specializing in such areas as IT, tutoring, online courses, beauty industry may become the most promising in the market of additional specialized education.

- Self-employed citizens aged $35-45$ are the most promising in the market of general education, mainly in pension legislation.

- The accessibility of self-employed citizens as potential consumers of educational services can be ensured mainly through their official registration. The official registration of self-employed citizens can be stimulated by a) more favorable tax regimes for self-employed citizens, b) a
\end{abstract}

\footnotetext{
*Corresponding author: PVRazov@fa.ru
} 
simplified registration procedure, and c) the introduction of harsh administrative penalties for evading the registration.

\section{Introduction}

The purpose of the study is to substantiate the growth of self-employment as both the global [1-8] and the Russian trend. The increase in the number of self-employed citizens is inextricably related to the growth in the number of people who have an internal need in the additional basic and specialized education. Some authors found a correlation between the level of education and income [9-14].

The authors' tasks are to empirically identify the fastest growing areas of activity performed by self-employed citizens. It is obvious, for example, that the people engaged in transportation or providing fitness services need different educational programs.

Another task is to assess promising age groups in the growing trend of self-employment, which will become the basis for educational programs.

The rapidly changing world sets one more challenge to cope with. This is the accessibility of self-employed citizens to various educational projects. The accessibility of self-employed citizens can largely depend on their official registration. The authors' hypotheses to be confirmed empirically are as follows. The main incentives for self-employed citizens may include more favorable tax regimes for self-employed citizens, rather simplified registration procedure, and the introduction of additional harsh administrative penalties for evading the official registration.

\section{Methods}

For efficient forecasting, the inductive analysis method was chosen. This is when the current and previous situations in the self-employed market are examined, then the main factors of the market development are revealed, and the main reasons for the formalization of selfemployment are considered. Based on this, the prospects for increasing the self-employed citizens' groups as consumers of general and specialized education are defined.

Empirically the study was based on the expert survey $(\mathrm{N}=228)$, the in-depth interview, the analysis of dozens of Internet publications [15] from various information resources, and the content analysis on the issues under study. It is necessary to mention that since 2012, the Russian Internet service YouDo.com has been the first information channel that initiated a virtual platform for self-employed citizens where they could sell their services. This channel could become an advertising space for educational offers for self-employed citizens.

The experts included self-employed citizens with at least a year of experience working in Moscow, the Moscow Region, Tatarstan, and the Kaluga Region. The in-depth interviews were offered to highly competitive experts, i.e., heads of state and private enterprises facing the problem under study. Thus, according to the experts, for example, from the Eurasian Center for Human Resource Management, minimizing the costs on, e.g., the payroll budget (PB), specialized assessment of working conditions (SAWC), certification of a workplace, provision of work clothes, advanced training, etc. is rather considerable when comparing a full-time employee and a self-employed specialist, i.e., the desire to optimize costs by an employer as one of the national sources of the trend for increasing the number of selfemployed citizens is shown.

The official data of the International Monetary Fund, the World Bank, the United Nations, the Organization for Economic Cooperation and Development, the International Labor Organization, statistical services of certain countries, as well as the Federal State Statistics Service, the Ministry of Labor and Social Protection of the Russian Federation, the Ministry 
of Finance of the Russian Federation, the Ministry of Economic Development of the Russian Federation, and the Pension Fund of the Russian Federation were used as the statistical base of the study.

\section{Results}

Let us pay attention to the conclusions by clusters of self-employed citizens of the Russian Federation.

Firstly, three areas that have the greatest growth potential are the following.

IT services are the most promising due to the IT development. Nowadays there are many areas that use these technologies, and each has its own specific tasks solved by sector-specific specialists that may include self-employed citizens. For example, there is a recent review of vacancies from the newspaper Vechernyaya Moskva [16]: an iOS developer - a salary of RUB 300 thous. per month, a developer of integration solutions - a salary of RUB 230 thous. per month, and an HR Director in the IT area - a salary of RUB 200 thous. per month. Moreover, actual salaries of highly qualified workers in a promising company are much higher than those offered in these vacancies.

Educational services (tutoring, online courses) are closely related, first of all, to the IT development. The development of the Internet and the availability of technologies for masses allowed online learning, including online tutoring. Another factor in the development of this area is the introduction of the Unified State Examination that requires not only knowledge, but also applied skills in various school disciplines.

Beauty services enter the area of self-employment that includes the activities requiring certain human skills. Therefore, the area also has a powerful growth potential due to changes in consumer attitudes in terms of individualization.

Secondly, the age and social status are as important in determining the potential of selfemployed citizens [17] as clients of the Russian Pension Fund. The most promising age category according to the potential criterion of the funded component of the pension provision of citizens is the people aged $35-45$.

Thirdly, the official registration of self-employed citizens can be stimulated by more favorable tax regimes [13, 18, 19] for self-employed citizens and more simplified registration. In addition, most experts note that the introduction of harsh administrative penalties for evasion will greatly increase the number of registered self-employed citizens. The authors determined the willingness of self-employed citizens to work officially.

Thus, the first ten areas of the ranks formed by the expert community (having more than half of the positive expert ratings) will be considered as the most promising clusters of selfemployed citizens in the Russian Federation in terms of pension contributions. These are IT services $(95.45 \%$ of the number of experts surveyed), tutoring $(86.36 \%)$, beauty services $(72.73 \%)$, animation and organization of holidays $(70.45 \%)$, confectionery and culinary services $(65.91 \%)$, fitness and sport services $(63.64 \%)$, child care $(61.36 \%)$, road transport services $(59.09 \%)$, domestic help (56.82\%), and construction and repair (54.54\%).

In addition to potentially promising clusters, it is necessary to understand what can be done to bring self-employed citizens out of the shadows. It is possible to take the measures offered by the experts and encourage people to officially register as self-employed citizens: eliminating fear of inspections and penalties $(75.0 \%)$, the possibility to commercially advertise goods and services $(68.2 \%)$, the possibility of decent retirement benefits upon reaching the retirement age when a person is healthy, full of energy, leads a full-fledged lifestyle $(61.4 \%)$, the introduction of harsh administrative penalties for evading the official registration $(60.5 \%)$, official confirmation of income $(54.6 \%)$, social advertising on financial benefits of official registration $(54.5 \%)$, accrual of seniority since the registration 
and interaction with the Pension Fund of the Russian Federation (50.0\%), and the introduction of compulsory pension contributions at the minimum rate $(47.8 \%)$.

\section{Discussion}

According to the authors of the work, the growth of self-employment is caused by main five trends.

The global trend of growth in labor productivity (IT, the growth of robotics and automation of productions, the improvement of remote employment opportunities, the increase in the financial and technical literacy of the population, the activation of online exchange services, the formation of a digital economy, etc.) at a certain enterprise of any form of ownership reduces the number of full-time employees, which is a potential for increasing the number of self-employed citizens in the region.

Economic problems in the country (the decrease in the actual income of the population, the growth of regional unemployment, enterprises of various forms of ownership do not always provide their employees with social packages that meet today's needs of people, etc.) are also a potential for increasing the number of self-employed citizens in the region.

The changing needs of employers (the desire to optimize costs, the need to search for highly qualified personnel whose salaries do not match the personnel policy of the enterprise, the ability to quickly find the required specialists, etc.).

The actual needs of employees [20-23], people living in the third millennium (potential self-employed citizens) (the desire of citizens to devote more time to their personal lives, the need of employees to regulate income by the time and amount of financial resources, the desire for flexible working conditions, etc.)

The needs of the market providing consumers with various services (individual, fairly differentiated needs of the modern market of services that are "not interesting" for medium and small businesses, the emergence of new attitudes among the population and potential consumers, etc.)

According to various sources [24], nowadays there are approximately $16-17$ million of unregistered self-employed citizens in the Russian Federation, which is about a quarter of all employees. According to other sources, the number of self-employed citizens was $11-18$ million as on 2018 [25].

These indicators once again prove the thesis about the growth of the self-employment. Moreover, in one of the in-depth interviews, one of the experts, an employee of the Financial and Banking Association of Eurasian Cooperation, paid attention to the trend related to the "transition" of citizens with the status individual entrepreneur to the status of self-employed citizen. In addition, the potential of such transitions is extremely considerable.

\section{Conclusion}

1. In the medium term, the number of registered self-employed citizens in the Russian Federation is going to increase during $5-10-15$ years (as to 01.01.2019): $2020 \sim 150 \%$, $2025 \geq 300 \%, 2030 \geq 500 \%$, and $2035 \geq 700 \%$.

2 . The growth is determined by five main trends displacing employable citizens from the classical area of employment: the growth in labor productivity as a global trend, problems in the socio-economic area of the country, the changing needs of employers striving to optimize costs, some employees' wishes to reduce hours of employment and individual planning of income, and needs of the consumer market of various individualized services that is unprofitable for a medium and even small business. 
3. Three areas that have the greatest development prospects are IT, educational (tutoring, online courses), and beauty services.

4. The official registration of self-employed citizens can be stimulated by more favorable tax regimes than for medium-sized, small businesses, and individual entrepreneurs, simplified registration of self-employed citizens, and toughening the administrative responsibility for the evasion from taxes.

5. According to the potential of the pension accumulation component, the most promising age category is the people aged $35-45$.

6 . The expected leader in the total number of registered self-employed citizens is the city of Moscow followed by the Moscow Region, Krasnodar Territory, the Republic of Tyva, and St. Petersburg.

7. Self-employed citizens have a real need in the state pension provision. The real income of a self-employed citizen that is a sociological indicator of the willingness of voluntary pension insurance is at least one million rubles a year.

8. The growth of the real professional potential of a self-employed citizen is expressed in his need in modern digital education. The realization of this need requires further scientific research, including empirical measurements in a monitoring mode.

\section{References}

1. M. T. Wolfe, P. C. Patel, J. Bus. Ventur. Insights, 12 (2019)

2. N. Bosch, H.-W. de Boer, Labour conomics 58 1-20 (2019)

3. M. Cowling, J. M. Millán, W. Yue, J. Bus. Ventur. Insights 12 (2019)

4. M. Barisione, D. De Luca, Electoral Studies 52, 84-93 (2018).

5. J. I. Gimenez-Nadal, J. A. Molina, J. Velilla, J. Transp. Geog. 66, 19-29 (2018)

6. M. Skrzek-Lubasińska, J. M. Szaban, Europ, Manag, J. 37(3), 376-386 (2019)

7. Y. Li, M. Mastrogiacomo, S. Hochguertel, H. Bloemen, Labour Econ. 41, 280-290 (2016)

8. P. C. Patel, M. T. Wolfe, T. A. Williams, J. Bus. Ventur. 34(4), 731-751 (2019)

9. C. A. Rietveld, J. Hessels, P. van der Zwan, Econ. Human Biol., 17, 59-74 (2015)

10. J. Olsen, M. Kasper, Ch. Kogler, S. Muehlbacher, E. Kirchler, J. Econ. Psy. 70, 125-139 (2019)

11. T. S. Gallen, J. Macroecon. 55, 184-198 (2018)

12. M. Koch, S. Park, S. A. Zahra, J. Bus. Ventur (in press) (2019)

13. P. Engström, J. Hagen, Europ. Econ. Rev. 92, 92-109 (2017).

14. K. Lim, K. Michelmore, Labour Econ. 55, 98-115 (2018).

15. YouDo.com. Pokolenie mobail ili chto proishodit s rynkom truda [Mobile Generation or What Happens to the Labor Market]. Research of YouDo.com, RAEC, RANEPA, supported by Google, ePayments. Available at: https://youdo.com/files/Youdo_ReportOnline Generation.pdf

16. N. Mironov. Moskva Vechernyaya 122(908) November 6 (2019) Available at: https://files.vm.ru/pdf/2019.11/original/5dd5774082682c1819ac5881.pdf

17. M. T. Wolfe, P. C. Patel, J. Bus. Ventur. Insights 9,45-52 (2018)

18. M. Fritsch, A. Sorgner, M. Wyrwich, J. Bus. Ventur. 34(6), (2019)

19. B. T. Heim, I. Z. Lurie, J. Health Econ. 28(6), 1197-1210 (2009)

20. S. V. Wichelen, J. Turčínková, Proc. Econ. Finance 12,761-770 (2014). 
21. Sh. W. Reid, P. C. Patel, M. T. Wolfe, J. Bus. Ventur. Insights 9, 128-136 (2018)

22. L. Spierdijk, G. van Lomwel, W. Peppelman, J. Health Econ. 28(6), 1185-1196 (2009)

23. J. N. van Ommeren, J. W. van der Straaten, Regional Sci. Urban Econ. 38(2), 127-147 (2008)

24. RANEPA. RANEPA poll: in Russia, about 17 million self-employed - a quarter of the working population (2019) Available at: https://social.ranepa.ru/novosti/item/socoprosranhigs-v-rossii-okolo-17-mln-samozanyatyh-chetvert-ot-rabotayushhego-naseleniya

25. V. Nazarov, Nalogovaya usluga: kak zastavit samozaniatyh vyiti iz teni [Taxation Service: How to Stimulate Self-Employed Citizens to Come Out of the Shadow] (2019) Available

at:

https://www.rbc.ru/opinions/economics/15/03/2019/5c8a1f419a7947ede48a7741 